\title{
Racialization, Between Power and Knowledge: A Postcolonial Reading of Public Health as a Discursive Practice
}

\author{
PATRICK CLOOS \\ Université de Montréal
}

\begin{abstract}
This paper presents and discusses the interdisciplinary theoretical perspective that has been built from a doctoral research on contemporary notions of "race" in the field of public health in the United States. In this context, "race" was seen as an object that emerged from the discourse, lying between power and knowledge as suggested by Foucault, while public health is an apparatus that put the discourse and the formation of the object into operation. Some authors in the field of postcolonial studies emphasize the representational power associated with the discourse that corresponds to a system of opposition and difference creating a dichotomy and ensuring the domination of some over others. This article argues that "race", as an idea of difference, will persist as long as historical conditions and people allow it.
\end{abstract}

\footnotetext{
${ }^{1}$ This article is a translation from: "La racialisation, entre pouvoirs et savoirs : une lecture postcoloniale de la santé publique comme pratique discursive," Aporia, 2(4), pp.29-35.
} 


\section{Introduction}

The contemporary discourse on 'race' in the United States is viewed as a pale reflection of what it was in the 19th century (Appiah, 1998). Several teams of anthropologists, sociologists and geneticists from Europe, United States, Mexico, India or Brazil met several times during the second half of last century at the initiative of the United Nations Educational, Scientific and Cultural Organization (UNESCO) to write four statements on 'race and racism' that were published between 1950 and 1967. Four statements were necessary to that institution and representatives of social and biological sciences to discuss and attempt to demolish the foundations of the racist discourse that these disciplines had in the past helped develop, in both the U.S. and Europe. They were no longer speaking of inequality but rather of racial equality.

The statements emphasized the unity of humanity and membership of all humans to one species Homo sapiens (Montagu, 1972). In these texts, scientists led by UNESCO have broken with the trends of both organizing human groups into a hierarchy and homogenizing them. The idea of racial superiority was now, at least scientifically, much more difficult to support (Barkan, 1992). However, according to the rapporteur of the second committee meeting on the initiative of UNESCO, races still exist and the proof is in the street (Montagu, 1972). At the time, says Brattain (2007), few scientists were ready to disown the scientific dimension of the category of

race. The author adds that this episode demonstrated the social construction of the category which was indeed reformulated by UNESCO. 
While recognizing that biological determinism did not completely disappear after the Second World War, Stepan (1982) thinks that the scientific racism that prevailed during the period 1800-1950, is a story of the past. In addition, says the author, most scientists have since relinquished the need to classify human groups while comparing the 'other'to an idealized 'self'.

Yet today, 'race' seems refluxed with tenfold intensity, suggests Dorlin (2009). Others noted an intensification of use of the category of race in Public Health, in the United States (Dressler, Oths, \& Gravlee, 2005). Based on recent research of the term 'race' in the database ISI Web of Knowledge, I have indeed found that for a decade, the use of the category of 'race' is steadily increasing in the sciences and it is in public health in the U.S. that this practice seems to be more frequent, if one believes the number of publications referenced by ISI Web of Knowledge.

In addition, a search of the word race' for this domain brings about four times as many documents (943) in 2009 compared to 2001 (251). This is probably related to the decision of the Clinton administration in the late 1990 to finance public health research in order to eliminate in the United States the phenomenon described as racial disparities in health (U.S. Department of Health and Human Services, 1998). Some authors, emphasizing social justice as a fundamental value of modern public health, support and encourage the use of this category in health research, the only possibility, they said, to study both the deleterious effects of racism and racial disparities in health (Krieger \& Birn, 1998; Thomas, 2001). According to Fee (1993), we cannot 
think and talk about health and wellness in the U.S. without addressing the issue of race and racism. In this sense, one can see the 'race' as a category of critical analysis (Dorlin, 2009) However, more than ten years ago, Fullilove (1998) proposed that in public health studies, a category that refers to the idea of hierarchy and that, in the past, justified the slave trade and slavery, should be abandoned. According to Bibeau (2002), the notion of 'race' is impertinent because, first, it does not properly render difference and secondly, it marks the return of racism to science and underlies ideas about human hierarchy based on biological and genetic differences.

The present article is from my doctoral thesis on contemporary conception of 'race' in the field of public health in the United States. This study was based on the analysis of a series of papers published between 2001-2009 in public health, in both scientific and government realms, and aimed at reconstructing the processes of its formation and describing the rules of these operations.

The purpose of this paper is primarily to present and discuss the interdisciplinary theoretical perspective that has been built in this research: I came to situate this form of difference not only among powers, discourse and knowledge but also between the past and the present of the Imperial encounter (Said, 2000). This approach emphasizes not only the political meaning of 'race' (Dorlin, 2009), but also its close links with sciences (Bibeau, 2002; Gould, 1996), and colonialisms (Appiah, 1998; Kapila , 2007; Loomba, 2005). Said (2000) notes the persistence of an 'imperial culture' found notably in the contemporary scientific practice in the 
United States, resulting in an unequal relationship between the observer and the subject of research and leading to 'otherness' in order to produce difference.

\section{The Emergence of 'Race' Within the Discourse}

We think something according to the discourse that prevails at a given time, says Foucault (1969). 'Race' has been seen in this work as an object of discourse, a discourse that is subject to a set of historical conditions that allow for saying something about it. This does not mean that there is not something out there, to which the idea refers. Rather, it means that it is the discourse, as an a priori and singularity, which allows us to know what it refers. And, if knowledge about the world is constructed within the discourse, discourse is not conforming to reality (Veyne, 2008).

The discourse shapes the object of knowledge, the ways to talk and think about it, the practices and the ways to behave in relation to it (Hall, 2003). It is the network consisting of heterogeneous devices including institutions, norms, techniques, types of classification, modes of characterization, which determines the ways one name, analyze and explain an object and that ensure its formation at a moment of history, says Foucault (1969).

All the practices and rules that will bring out, define and specify an object of discourse at a given time, can be qualified as a discursive formation. In other words, according to Foucault, wrote Hall (2003), it is in a discursive formation that a given object appears as an intelligible construct. According to Lidchi (2003), a discursive formation refers to an operation that 
constitutes a body of knowledge, which constructs an object in a certain way while limiting other ways of construction . Such a formation, adds Lidchi, includes several discourses. The study of the object therefore requires an analysis of its formation in the discourse which, Foucault (1969) writes, is not confined to language but rather must be seen as practices that systematically form the objects of which they speak. What are the elements that have implemented the idea of 'race' and thereby constitute a body of knowledge about it? Before providing some answers to this question, I propose to put this idea in relation to power.

\section{Racism, a Power Over Death}

'Race' is seen as a form of differentiation, such as 'sex' and 'class', which is used to produce differences and distinctions (Dorlin, 2009). According to Foucault (1997), races emanate from racism, a technology of the modern state which is a power to death. The first function of racism, says Foucault, is the fragmentation of humanity into a mixture of races while its second function is to establish a biological relationship 'between my own life and the death of the other'. The 'inferior races', the 'abnormal' and the 'degenerate' represent a danger to be eliminated in order to make life healthier. It is through racism, think Foucault, that we are witnessing the development of oppositional relationships between the normal and abnormal, the healthy and the degenerate and the superior and inferior. 


\section{Race, Object of Differentiation and Domination}

Racial difference has been shaped by three encounters, said Hall (2003): the transatlantic slave trade, modern colonialisms and recent migrations in Europe and North America. The emergence of 'race' as an object of discourse has thus spread over the last centuries and engaged colonizing and colonized societies, not only through their political and scientific institutions but also their legal and military, and a multitude of practices that shaped and circulated images about the racialized 'other'.

Politicians and scientists in the last few centuries, depending on the time and place, distinguished humanity into racialized groups from which they described individuals, weighed and measured their skulls, drew and colored their bodies, then compared them to establish a hierarchy according to aesthetic characteristics to which they associated attributes sometimes mental sometimes moral or even sexual (Appiah, 1998; Bibeau \& Pedersen, 2002; Gould, 1996; Loomba, 2005). It is therefore essential to understand that the body has become a discursive site to represent difference and to produce a racialized knowledge (Hall, 2003); a form of knowledge that accompanied the concomitant development of nation states in Europe and North America (Loomba, 2005). In the excerpt below, the future President Jefferson's writings illustrate the direction taken by the racial thought in the late $18^{\text {th }}$ century in the United States which finds then one of its anchor points in the political world:

The real distinctions which nature has made; and many other circumstances, will divide us into parties, and produce convulsions which will probably never end but in the extermination of the one or the other race. To these objections, which are political, may be added others, which are physical and moral. The first difference 
which strikes us is that of colour. Whether the black of the negro resides in the reticular membrane between the skin and the scarf-skin, or in the scarf-skin itself; whether it proceeds from the colour of the blood, the colour of the bile, or from that of some other secretion, the difference is fixed in nature, and is as real as if its seat and cause were better known to us (...). They [the blacks] are more ardent after their female; but love seems with them to be more an eager desire than a tender delicate mixture of sentiment and sensation (...)". Comparing them by their faculties of memory, reason, and imagination, it appears to me, that in memory they are equal to the whites; in reason much inferior (...) (Jefferson, 1781-82, in Appiah, 1996, pp.4445).[1]

It is the body which now informs, establishes and explains difference (Appiah, 1998).

Meanwhile, after a one year trip (1831-1832) in The United States, Alexis de Tocqueville wrote in De la démocratie en Amérique, a title for the less ambiguous:

The men scattered in this space do not form, as in Europe, as an offshoot of the same family. We find in them, at first sight, three naturally distinctive races, and I might almost say enemies. Education, law, origin, till the external shape of the traits had elevated between them an almost insurmountable barrier, fortune has brought them together on the same ground, but she has mixed them without being able to confound them and each continues to share his fate. Among these men, so different, the first that attracts attention, the first in light, in power and happiness, is the white man, the European, man by excellence, and below him appear the Negro and the Indian (p.467). ${ }^{2}$

Codes and laws were developed and implemented throughout the $19^{\text {th }}$ and $20^{\text {th }}$ centuries in the United States and elsewhere to regulate the rights, freedoms, duties, status and social identity of each according to skin color (Bessone, 2004). Colonialism, through wars first and then textuality, is seen as a discursive formation which confined colonized subjects to a representational system (Tiffin \& Lawson, 1994). Representations about the racialized 'other'

\footnotetext{
${ }^{2}$ The translation is from the author.
} 
varied depending on the colonial and political imperatives (Loomba, 2005). Said (1978) was interested in representations of the Orient found in Orientalism. The author was not really interested in whether or not the discourse corresponds to a potential reality about the Orient. There is, writes Said, nations, people and cultures in the region referred to as the Orient. Rather, the author was interested in the consistency of ideas that are carried in the discourse about 'Orient'. This discourse, which is the source of knowledge about the Orient is inscribed in power relationships, thinks Said.

Moreover, the setting up of boundaries, Said (2000) wrote, involves mechanisms of authority, domination and sovereignty. Similarly, Hall (2003) suggests that Orientalism produced through representations a knowledge about the racialized 'other' which is inscribed in operations of power. Orientalism is an authoritarian discourse, both political and academic of the West that, since the Enlightenment, consisted to direct, produce and dominate the Orient, thinks Said (1978). Orientalism is a discourse that describes not only the Orient but that imposed the way of thinking and talking about it.

For its part, Obeyesekere (1992) argues that cannibalism described in the $19^{\text {th }}$ century is a discourse. The author suggests that this type of discourse talks more about the relationship between the author (the ethnographer) and social actors (Hawaiians), and also about the concern of the author more than about the phenomenon. The discourse, therefore, according to Obeyesekere, has a dialogic nature insofar as it is accompanied by a process of otherness, where the 'other' is represented in a particular way: it defines the 'savage' behavior by describing and 
assigning practices. From his own experience, Fanon (1971) describes the colonial situation and his transformation, an operation that goes through 'details, anecdotes and stories.' A transformation that is described as irrational by the author and is focused, above all, on the body and sexuality. The 'White', suggests Fanon, needs to characterize the 'other'. The reality of the 'Black' is in its relationship with the 'White', adds Fanon, who has transformed his body image in a racialized epidermic pattern.

\section{Public Health or the Paradox of Discourse}

From the 18th century, Public health gradually became a field of knowledge, writes Fassin (2005), following the application of various disciplines to the health domain and the transition from an individual perspective to a collective level. However, if public health is a field of knowledge, it first expressed a power, adds Fassin. Public health expresses a biopower (biopouvoir), a state and institutional technology of intervention on life, which, Foucault (1976; 1997) writes, has emerged these last centuries to discipline bodies and control population phenomena to normalize behaviors and prolong life.

The establishment by the political authorities of the first sanitary apparatuses in Europe since the late $15^{\text {th }}$ century (Fassin, 2005), has been accompanied by attempts to control certain groups suspected of threatening public order (Porter, 1999), and seems to announce from the 17th century the transformation of modes of operation of the modern state, described by Foucault (1976; 1997). In a context of urbanization, population growth and industrialization, life and the 
biological are taken care of. The first set of mechanisms of that biopower seeks to discipline the body.

This is, according to Foucault (1976; 1997), a whole system of life administration and management which is institutionalized to enhance skills and performance of the human body for the benefit of working through institutions like the hospital. The other side of this technology rather seeks to control population phenomena by the establishment of regulatory mechanisms: insurance and health care services and hygiene rules, for example. Bio-regulation, Foucault writes, which is centralized and coordinated by the state, is primarily to ensure population control in problematizing phenomena such as birth, death and disease.

Thus, public health has not to be seen simply as a fact of nature that would affect the community, suggests Fassin (2005). It is rather the result of a series of operations that transform a social situation into a sanitary problem. This process of health problematization is shaped by operations of medicalization and politicization, writing Fassin, which refer to a set of medical, media and political interventions. Moreover, medical language is transformed into health/sanitary terms through discipline techniques: in public health, we talk about screening, frequency, risk, preventative measures, and groups. Public health, a vast territory with boundaries that are both indistinct and dynamic (Fassin, 2005; Gagnon \& Bergeron, 1999) has been seen in this context as a set of practices that shape its objects while making itself (Foucault, 1969; Fassin, 2005). That is, as a field of differentiation that finds opportunity to create and describe its objects and give them a status (Foucault, 1969). 


\section{Racialization of Public Health: Representing to Oppose and Control}

According to Fassin (2005), the hygienist trend is a continuation of the Enlightenment: the major objective is to ensure the progress of humanity while improving and normalizing unequal situations. However, this observation is somewhat paradoxical if one accepts that 'Enlightenment' also laid the foundations for racial classification (Appiah, 1998; Bibeau \& Pedersen, 2002; Loomba, 2005), and secondly, as a homogenizing project, the state has continually produced difference for excluding and stigmatizing (De Boeck, 2005). By using 'race', public health is inscribed in the process of differentiation that aims at identifying people based on physical characteristics, as blurred they are (Appiah, 1998). Public health appears finally as a discipline, an apparatus as Veyne (2008) would say, which, by its practices and techniques, implement the discourse on 'race'. That means that making knowledge about public health according to 'race' requires a fragmentation of the population in which racialized groups, conversely, are made up in medicalized terms. Racialization thus enables medicalization by transforming undifferentiated individuals into a collective and differentiated entity.

Two processes are intermingled with the first dividing the population and locating groups against each other and the second, describing them from a sanitarian point of view. One consequence of these operations is the characterization of both the disease and groups (Hacking, 1992). In Los Angeles in the early 20th century, for example, public health participated in racializing the population and constituting the Chinese first and then the Japanese as the racialized 'other', Molina (2006) says. The author suggests that public health has, by formal and 
informal connections with the political, business and media domains, helped shape social order in racializing and stigmatizing certain groups. Thus, the opposition relationship between racialized groups became a principle of social organization in which public health participated. Thus, the lack of hygiene was mainly attributed to some immigrants then perceived as a threat to the health of the rest of the urban population. For Molina, the public health community have instilled in political, media and legislative discourses, elements that served to legitimize and reinforce racial hierarchy and segregation.

According to Hall (2003), the creation of stereotypes play a major role in the representation of racial difference. This operation helps to reduce some groups to a few characteristic and simplistic images, this to confirm the symbolic order. Stereotypes refer to as much an imagined and fanciful world as a world perceived as real, says Hall. This process tends to exclude the same from different: it sets symbolic limits and excludes everything that does not belong to it.

Similarly, colonial public health practices in the Philippines, in establishing rules of behavior of the American soldier in the tropics, have shaped the image of the 'White' as opposed to the 'other' (Anderson, 2006). Therefore, the principles and practices of Tropical Hygiene would gradually regulate the everyday life of the American soldier, says Anderson, who was encouraged to dress and behave in a certain way to avoid sinking into sickness and madness. Instead, Filipinos and Chinese were described, for example, as naturally more prone to heavy work. 
Fee reminds us that not so long ago, public health services in Alabama conducted an experiment to observe the clinical course without treatment, of four hundred so-called black patients who suffered from syphilis (Fee, 1993). This experiment that started in 1932 stopped in 1972, long after the antibiotic penicillin was proven to be beneficial to treat this potentially fatal disease. More recently, medicine and public health participated in the circulation of exotic thesis about the origin and epidemiology of AIDS in the 1980 (Farmer, 1996). Many American doctors who suggested an association between HIV transmission and cultural voodoo practices consequently, stigmatized the Haitian population.

\section{In Conclusion: The Discourse of Other Possibilities}

The theoretical perspective presented in this paper suggests on the one hand not to separate 'race' from the idea that one makes of difference at a given time and, secondly, to situate this kind of differentiation within operations of power. In this sense, it is the idea that makes 'race'. This idea is put in operation by a discursive process, racialization, which corresponds to all operations, institutions, practices, techniques and representations that set the rules of the ways to think difference and whose racialized objects are the result. This process includes a particular classification, an operation that not only consists in identifying people but also locating groups in relation to each other on the political scene (Appadurai, 2005). Racialization is a differentiation that focuses on the body and that prevails still today in public health. 
Public health has been seen here as a device that shape and delimit 'race' and that has the role, with others devices, to name, designate, describe and create 'race' as an object of discourse. The discourse on 'race' is an expression of state power, racism, as suggested by Foucault (1997) which ensures the production of difference. Public health has therefore the role to put this discourse in operation by producing a racialized and medicalized difference which is inscribed in relationships of opposition and domination.

This means that if the discourse tends to impose itself on everybody, dominated as dominant, (Veyne, 2008) it conveys, through its representations, the creation of this dichotomy (Loomba, 2005). According to Abu-Lughod (1991) race is a system of difference that responds, like gender and class with which it is related, to a logic of opposition.

Therefore, the use of 'race' as a category of analysis even from a critical perspective should not overshadow the risk of reification (Brattain, 2007; Loomba, 2005) in the sense that the mobilization of such an idea triggers the process and the power that create it. Thus, in seeking to claim the power of representation, the so-called postcolonial perspective runs the risk, perhaps paradoxically, to make the game of colonial discourse.

What about postcolonial practices that homogenize, universalize and generalize and finally tend to naturalize the 'White', the 'European culture' or 'the West' while denouncing their domination? Today, the level of globalization crystallizes the tension between homogenizing and heterogenizing forces, between policies of similarity and difference, writes Appadurai (2005). The state tries to exercise a taxonomic control on difference via images to domesticate 
difference, adds Appadurai. The author seems to think that institutions such as the state do not offer other options than thinking about difference in certain terms.

There is a battle of the imagination between the state and the groups of the nation, according to Appadurai (2005), in so far as the political ideas and aspirations of identity of the latter seek to transgress the boundaries of the nation-state, a situation that seems to be difficult for the state to tolerate since they threaten its control. It seems to me that the restriction of categories and images leads to the limitation of the possibilities of being. In other words, racialization prevents to think other possibilities. This idea of possibility is discussed by Hacking (1992) who is interested in what makes people or more exactly what people might be. The author suggests that the political and medical discourses have generated a proliferation of labels and, concomitantly, types of people.

The dynamic nominalism, described by Hacking (1992), suggests that many people and human acts 'come into being' at the same time that the categories that label them. This would mean that the space of possibilities, describes by Hacking is, to some extent, shaped by the way things are named and described. However, if new technologies of power have emerged to try to manage life and death, this does not prevent individuals from using their own freedom in responding to the rules and constraints that discourse imposes, to be themselves a model for others, writes Hacking (1992). We must therefore see the relevance of the concept of discourse of Foucault: a tool for critical analysis and resistance, as noted by Nicholls (2009) mentioning Hook. 'Race' will continue to exercise its related power until racialization will persist. 
Conversely, it is likely that 'race' will disappear when all the components of this form of discourse on difference, and not just stereotypes, will be dismantled. It seems however that the ethnic discourse, and more broadly culturalism, as another system of opposition and difference, has already secured the heritage of the racialized regime of representation (Hall, 2003).

\section{Acknowledgments}

The author wishes to thank the Council of Humanities Research of Canada for the PhD scholarship granted to him to achieve his research (No.752-2007-1215). 


\section{References}

Abu-Lughod, L. (1991). Writing against culture. In R.G. Fox (Ed.), Recapturing Anthropology : Working in the Present (pp.137-162). Santa Fe: School of American Research Press.

Anderson, W. (2006). Colonial Pathologies: American Tropical Medicine, Race, and Hygiene in the Philippines. London : Duke University Press.

Appadurai, A. (2005). Après le colonialisme: Les conséquences culturelles de la globalisation. Paris: Payot.

Appiah, K.A. (1998). Race, Culture, Identity: Misunderstood Connections. In K.A. Appiah \& A. Gutmann (Eds.), Color Conscious: The Political Morality of Race (pp.30-105). Princeton: Princeton University Press.

Barkan, E. (1992). The Retreat of Scientific Racism, Changing concepts of race in Britain and the United States between the world wars. New York: Cambridge University Press.

Bessone, M. (2004). Postface. In W.E.B. Du Bois, Les âmes du peuple noir (pp.271-337). Paris: Éd. Rue D'Ulm.

Bibeau, G., \& Pedersen, D. (2002). A return to scientific racism in medical social sciences: The case of sexuality and the AIDS epidemic in Africa. In M. Nichter, \& M. Lock (Eds.), New Horizons in Medical Anthropology (pp.141-171). New York : Routledge.

Brattain, M. (2007). Race, Racism, and AntiRacism: UNESCO and the Politics of Presenting Science to the Postwar Public. American Historical Review, 112, 1386-1413.

De Boeck, F., \& Plissart, M-F. (2005). Kinshasa, Récits de la ville invisible. Bruxelles: La Renaissance du Livre.

Dressler, W.W., Oths, K.S., \& Gravlee, C.C. (2005). Race and Ethnicity in Public Health Research : Models to Explain Health Disparities. Annual Review of Anthropology, 34, 231-52.

Fanon, F. (1952/1971). Peau noire, masques blancs. Paris : Seuil.

Farmer, P. (1996). Sida en Haiti. La victime accusée (trad. Corine Hewlett). Paris : Karthala.

Fassin, D. (2005). Faire de la santé publique. Rennes: Éditions de l'école nationale de la santé publique. 
Fee, E. (1993a). The Wages of Sin ? Struggles over the Social Meaning of Veneral Disease and AIDS. In Y. Kawakita, S. Shizu, \& Y. Otsuka (Eds.), History of Epidemiology, Proceedings of the 13th International Symposium on the Comparative History of Medicine - East and West (410 Sep., 1988), Japan: IshiyakuEuroAmerica Inc. Publishers, 161-189.

Foucault, M. (1969). L'archéologie du savoir. Paris: Gallimard.

Foucault, M. (1976). Histoire de la sexualité : La volonté de savoir. Paris : Gallimard.

Foucault, M. (1997). Cours du 17 mars 1976. In Il Faut Défendre la Société: Cours au Collège de France. 1975-1976 (pp.213-235). Paris : Gallimard/Le Seuil.

Foucault, M. (1999). Cours du 8 Janvier 1975. In Les Anormaux. Cours au Collège de France. 1974-1975 (pp.3-27). Paris : Gallimard/Le Seuil.

Fullilove, M.T. (1998). Abandoning 'Race' as a Variable in Public Health Research - An Idea Whose Time Has Come. American Journal of Public Health, 88, 1297-98.

Gagnon, F., \& Bergeron, P. (1999). Le champ contemporain de la santé publique. In C. Bégin, P. Bergeron, P. Forest., \& V. Lemieux, Le Système de santé québécois. Un modèle en transformation (pp. 229-258). Montréal : Les Presses de l'Université de Montréal.

Gould, J.G. (1996). The Mismeasure of Man: The definite refutation of the argument of the Bell Curve. New York: W.W. Norton Company.

Hacking, I. (1992). Making Up People. In E. Stein (Ed.), Forms of Desire : Sexual Orientation and the Social Constructionist Controversy (pp.69-88). New York: Routledge.

Hall, S. (Ed.) (2003). Representation: Cultural Representations and Signifying Practices. London: Sage.

Kapila, S. (2007). Race Matters: Orientalism and Religion, India and Beyond c.1770-1880. Modern Asian Studies, 41, 471-513.

Krieger, N., \& Birn, A-E. (1998). A Vision of Social Justice as the Foundation of Public Health: Commemorating 150 Years of the Spirit of 1848. American Journal of Public Health, 88, 16031605 .

Lidchi, H. (2003).The Poetics and The Politics of Exhibiting Other Cultures. In S. Hall (Ed.), Representation: Cultural Representations and Signifying Practices (pp.151-222), London: Sage. 
Loomba, A. (2005). Colonialism/Postcolonialism (2 ${ }^{\text {nd }}$ ed.). New York: Routledge.

Molina N. Fit to be Citizens? Public Health and Race in Los Angeles, 1879-1939. University of California Press, Berkeley, 2006.

Montagu, A. (1972). Statement on Race ( $3^{\text {rd }}$ ed.). New York: Oxford University Press.

Obeyesekere, G. (1992). "British Cannibals": Contemplation of an Event in the Death and Resurrection of James Cook, Explorer. Critical Inquiry, 18, p.630.

Porter, D. (1999). Health, civilization and the state. A history of public health from ancient to modern times. Part 1. Population, health and pre-modern states. London: Routledge, 10-61.

Said, E.W. (2000). Culture et Impérialisme (trad. Paul Chemla). Paris: Fayard/Le Monde diplomatique.

Said, E.W. (1978). Orientalism. New York : Vintage Books.

Stepan, N. (1982). The Idea of Race in Science: Great Britain 1800-1960. London: The MacMillan Press.

Thomas, S.B. (2001). The color line: Race matters in the elimination of health disparities, American Journal of Public Health, 91, 1046-48.

Tocqueville de, A. (1961). De la démocratie en Amérique. Paris: Gallimard.

Veyne, P. (2008). Foucault, Sa pensée, sa personne. Paris: Albin Michel. 